Article

\title{
Coping with Extreme Events: Effect of Different Reservoir Operation Strategies on Flood Inundation Maps
}

\author{
Elena Ridolfi ${ }^{1,2, *(\mathbb{D}}$, Silvia Di Francesco ${ }^{3}\left(\mathbb{D}\right.$, Claudia Pandolfo $^{4}\left(\mathbb{D}\right.$, Nicola Berni $^{4}$, \\ Chiara Biscarini ${ }^{5}$ and Piergiorgio Manciola ${ }^{6}$ \\ 1 Department of Earth Sciences, Uppsala University, 75236 Uppsala, Sweden \\ Centre of Natural Hazards and Disaster Science, CNDS, 75236 Uppsala, Sweden \\ Niccolò Cusano University, 00166 Rome, Italy; silvia.difrancesco@unicusano.it \\ 4 Centro Funzionale della Regione Umbria (CFD), 06034 Foligno, Italy; cpandolfo@regione.umbria.it (C.P.); \\ nberni@regione.umbria.it (N.B.) \\ 5 UNESCO Chair in Water Resources Management and Culture, University for Foreigners of Perugia, \\ 06123 Perugia, Italy; chiara.biscarini@unistrapg.it \\ 6 Department of Civil and Environmental Engineering, University of Perugia, 06125 Perugia, Italy; \\ piergiorgio.manciola@unipg.it \\ * Correspondence: elena.ridolfi@geo.uu.se
}

Received: 14 February 2019; Accepted: 5 May 2019; Published: 10 May 2019

\begin{abstract}
The need of addressing "residual flood risk" associated with structural protection measures, such as levee systems and flood-control reservoirs, has fostered actions aimed at increasing flood risk awareness. Structural measures have lowered risk perception by inducing a false sense of safety. As a result, these structures contribute to an underestimation of the "residual risk". We analyze the effect of different reservoir operations, such as coping with drought versus coping with flood events, on flood inundation patterns. First, a hydrological model simulates different scenarios, which represent the dam regulation strategies. Each regulation strategy is the combination of an opening of the outlet gate and of the initial water level in the reservoir. Second, the corresponding outputs of the dam in terms of maximum discharge values are estimated. Then, in turn, each output of the dam is used as an upstream boundary condition of a hydraulic model used to simulate the flood propagation and the inundation processes in the river reach. The hydraulic model is thus used to determine the effect, in terms of inundated areas, of each dam regulation scenario. Finally, the ensemble of all flood inundation maps is built to define the areas more prone to be flooded. The test site is the Casanuova dam (Umbria, central Italy) which aims at: (i) mitigating floods occurring at the Chiascio River, one of the main tributaries of Tiber River, while (ii) providing water supply for irrigation. Because of these two competitive interests, the understanding of different scenarios generated by the dam operations offers an unique support to flood mitigation strategies. Results can lead to draw interesting remarks for a wide number of case studies.
\end{abstract}

Keywords: flood risk; reservoir regulation; dam retention basin; residual risk; flood inundation map; extreme events

\section{Introduction}

To alleviate droughts and floods, human societies have built structural devices such as levee systems and reservoirs, which can significantly affect the hydrological regime. Specifically, they can alter droughts and floods in terms of their variability, frequency and magnitude [1]. 
Risk perception tends to decrease in areas protected by structural measures, as the reduced frequency of hydrological extremes is often associated with the fading awareness and preparedness of locals. In the literature, this phenomenon is known as the "safe-development paradox", which was introduced for the very first time by White [2] with reference to floods (known as "levee effect"), and more recently shown with reference to drought, and termed "reservoir effect" by Di Baldassarre et al. [3]. More specifically, the presence of structural protection measures can encourage the expansion of urban and industrial settlements in flood-prone areas and lead to catastrophic consequences, when a flood event characterized by a return period higher than the design value of the levee eventually occurs.

The presence of structural measures may cause a prolonged absence of extreme events, i.e., floods and droughts. In this scenario, the occurrence of an extreme event causes damages much higher than those due to extreme events occurring with a smaller inter-arrival time. The rationale of it is due to a continuous process of learning and forgetting that involves the population settled in the areas at risk. Indeed, several studies reported that long periods of "calm" fade the memory of locals, which are therefore more prone to not be aware of the risk and to pursue habits that do not cope well with hydrological extremes [4]. Community's risk perception can be rather low if the antecedent flood event occurred far back in time [5]. The low-risk awareness is among the main causes of low preparedness, which in turn generates an inadequate response to natural disasters [6,7]. Not only the occurrence of hydrological extremes, but also the perception of current and future risk shapes society [8]. However, if on one side population growth and societal development tied up societies and water demand, perception of relevant problems associated to water generally decreases with increasing societal development [9]. People who do not need to personally secure water and assess water-related risks tend to forget their state, losing contact with natural water systems and thus also losing the capability of perceiving risk. For instance, population living in flood prone areas may be not aware of the hydrological risk they face, as they feel protected by hydraulic structures such as dams and levee systems.

Dams and reservoirs have consistently increased in number in the last century because of their capacity of bridging periods of water scarcity, supplying water for diverse uses. Their role was to enable economic growth and poverty mitigation in many areas $[10,11]$. However, flow regulation below dams is a challenging task, which requires an interdisciplinary approach to take into account both physical variables and biota. Dam operation's effects on flood can cause hydrological alteration and ecological degradation whose evaluation and rehabilitation is commonly required by recent legislation (as the Water Framework Directive in Europe). Bizzi et al. [12] proposed a method to define an aggregate index of hydrological alteration that can be used to design minimum environmental flow and reservoir operation, useful to improve a real implementation of environmentally friendly policies. Bruno and Siviglia [13] contributed to the understanding of the consequences of dam operations to develop a unified view of the problems of flow regulation below dams. Richter \& Thomas [14], assessing the potential benefits of dam re-operation, formulated hypotheses about the ecological and social benefits. These hypotheses can be tested by implementing a re-operation plan, tracking the response of the ecosystem, and continually refining dam operations-through adaptive management and the creation of a "Flow Restoration Database".

The benefits depend on the management of these structures, for instance a catastrophic event is not only caused by the collapse or the failure of a dam [15], but can also be due to an unsuitable operation strategy. For instance, this is the case of the Brisbane dam in Australia. The reservoir was kept full to cope with the Millennium drought and thus it was not able to laminate the incoming flood wave with catastrophic consequences [16]. In this framework, it is of utmost importance to perform flood risk analyses at the proper level of detail [17] and to determine the effect of flood management strategies operated at each dam. The flood management is a set of activities aimed at preventing and reducing the flood risk and it is one of the most important non-structural actions for the management of residual risk. The flood management activity, and especially the regulation of outflows through reservoirs, is expected by the Flood Directive 2007/60/EC for the assessment and management of 
flood risk. The Flood Directive obliges to define a lamination plan for each dam. A lamination plan determines the volume in the reservoir that has to be kept dry to capture floodwaters for flood control purposes. A lamination plan may consider two different approaches, which are a "static programming" and a "dynamic programming", respectively. The static programming considers the maintenance of the water level in the reservoir at a value lower than the maximum authorized for the whole period of the year considered critical for the occurrence of flood events; while the dynamic programming considers the execution of maneuvers before or during the event on the base of both quantitative precipitation forecasted upstream of the dam and the status of the basin, i.e., the water level in the reservoir and the discharge that can be released downstream without causing flooding.

The dam case of study is the Casanuova dam, located in central Italy (Umbria region). The dam aims at mitigating floods occurring at the Chiascio River, one of the main tributaries of the Tiber River, in turn the second longest Italian river, and at providing water supply for irrigation purposes. These two competitive interests can result also in the management of the reservoir that should be kept as full as possible to satisfy the water demand, but also it should be kept empty to mitigate the incoming flood waves.

In this study, the effects of different management strategies of the Casanuova dam are analyzed. The two competitive interests influence the dam management and make the understanding of the effect of different operation strategies of utmost importance to define a lamination plan. Each operation strategy is the combination of a specific initial water level in the reservoir and a specific opening of the outlet gate. The consequent water discharged downstream may have different effects on the floodplain area, also causing flooding. The main idea is that a wide number of dam management actions can lead to flooding in the areas located downstream. This work aims at investigating the effect of dam regulations to understand which areas are more affected by flooding. The study is pivotal to better plan mitigation strategies, to pursue programs aiming to inform citizens, raise their awareness and thus preparedness to face an extreme event. This work is well placed within the framework of the International Association of Hydrological Sciences (IAHS) Scientific Decade 2013-2022, entitled "Panta Rhei-Everything Flows" [18]. The IAHS Scientific Decade focuses on the investigation and interpretation of the relationships existing between the processes of the water cycle and human society. The aim is to unravel the nexus between the environment and human systems to support a more sustainable societal development in a changing environment.

The paper is organized as follow: first the case study is presented together with the hydrological data used in the study. Second, the methodology is outlined presenting the cascade model used to simulate the regulation of the dam and to determine the flood inundation maps. Then, results are shown and conclusions are drawn.

\section{Case Study}

In this Section, first, the case study area will be detailed and the dam characteristics will be presented. Second, the case study area will be framed into the plan issued for the prevention and protection from hydrogeological risk (Hydrogeological Setting Plan-PAI). Then, the hydrological data used to implement the hydrological model will be reported.

\subsection{The Chiascio River Basin}

The Chiascio River is located in Central Italy and it is one of the main tributaries of the Tiber River. The Chiascio River originates from the Apennine ridges at an altitude of about $850 \mathrm{~m}$ a.s.l., the river length is about $80 \mathrm{~km}$ and the drainage area is about $730 \mathrm{~km}^{2}$. Calcareous and permeable rocks characterize the upper part of the basin; the middle part of the main geological formation is composed by flysch and the soil has low permeability, the downstream part is composed mainly by alluvial aquifers. The catchment has a complex orography that can significantly enhance the widespread frontal rainfalls causing major flood events. 
Along the river, both urban settlements and industrial areas are located; the main municipality is Bastia Umbra and Assisi.

The Casanuova dam was built in 80s-90s and it is an earth-filled dam with a trapezoidal shape. The main geometric characteristics of the dam are summarized below:

- $\quad$ Crest height: $338 \mathrm{~m}$ a.s.l.;

- $\quad$ Crest wideness: $14 \mathrm{~m}$;

- $\quad$ Minimum level of the reservoir: $270 \mathrm{~m}$ a.s.l.;

- $\quad$ Spillway elevation: $330 \mathrm{~m}$ a.s.l.;

- $\quad$ Outlet gate: circular shape with an area of $35 \mathrm{~m}^{2}$;

- $\quad$ Inlet elevation: $280 \mathrm{~m}$ a.s.l.

The dam subtends a drainage area of $\sim 470 \mathrm{~km}^{2}$ and the reservoir volume is $221 \mathrm{Mm}^{3}$.

\subsection{The Plan for the Prevention and Protection from Hydrogeological Risk}

For the Tiber River, and then for the Chiascio River, in the 2000s the Tiber River Basin Authority laid out a plan for the prevention and protection from hydrogeological risk (Hydrogeological Setting Plan-PAI) in collaboration with the Umbria Region. Subsequently, in 2015, the District Authority of the Central Apennines approved the Flood Risk Management Plan (Figure 1) as required by the Flood Directive 2007/60/EC. For the completion of the hazard map, the PAI identified three different types of flooding corresponding to low, medium and high probability of occurrence, in turn corresponding to a return period lower than or equal to 500, 100-200 and 20-50 years, respectively. For each scenario, the extent of the flood, the water level height and the characteristics of the flow are indicated. To map the flood risk, the PAI considered various elements, such as the number of potentially interested inhabitants, the strategic infrastructures and structures, the environmental, historical and cultural assets, the distribution and typology of the economic activities.

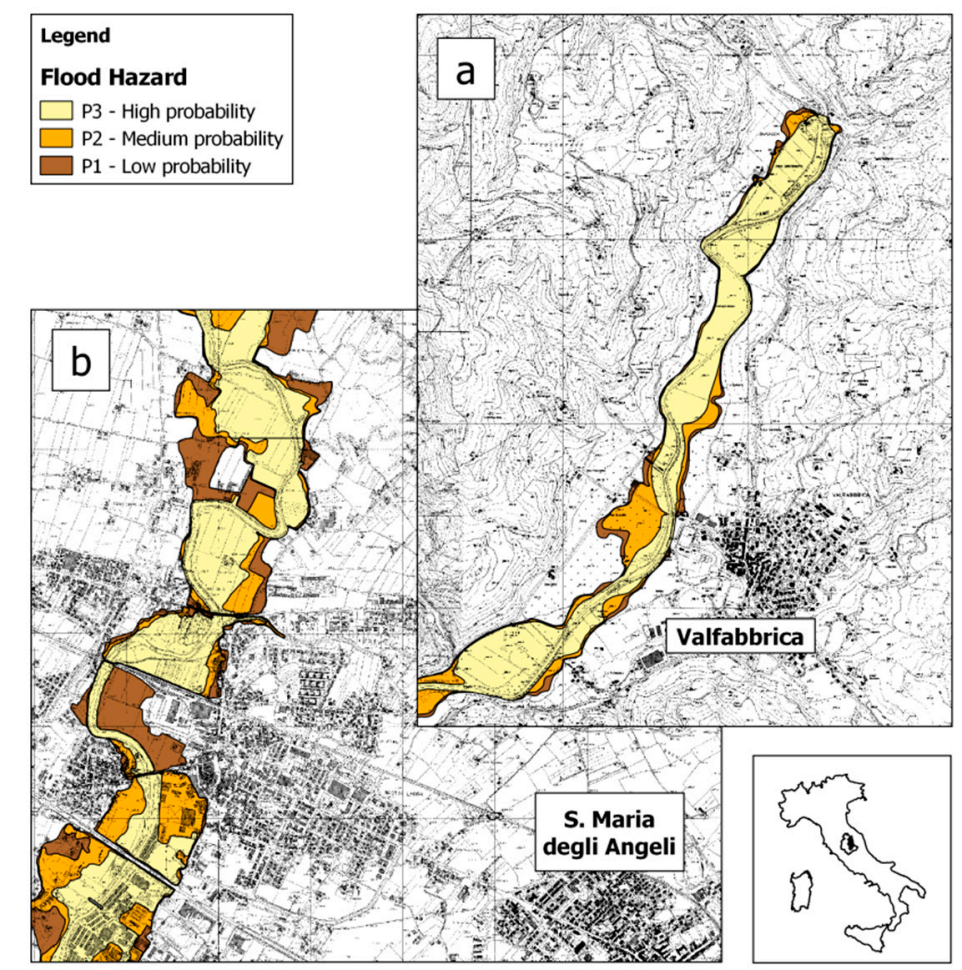

Figure 1. Localization of the case study area in central Italy. Flood Risk Management Plan: hazard map (high, medium and low probability) for areas surrounding the two towns of Valfabbrica (a) and Assisi (b). 
Since the PAI was performed before the construction of the dam, it does not consider the effects produced by the dam. Therefore, it is necessary to assess which areas would be flooded considering different regulation strategies of the dam to define suitable operative procedures needed to raise citizens' awareness and thus increase their preparedness to face the flood risk. Moreover, the evaluation of the areas that would be flooded considering different dam regulation strategies is of great importance to plan non-structural mitigation strategies such as early warning systems $[19,20]$.

As we aim to understand the role of the dam in relation to hydrological extremes (i.e., flood events), a major flood event characterized by a return period of 200 years and occurred in 2013 is considered and it is used as input for the dam. The peak discharge of the flood event is equal to $639 \mathrm{~m}^{3} / \mathrm{s}$, the duration of the event is equal to $63 \mathrm{~h}$, and the time to peak is around $26 \mathrm{~h}$. Several dam regulation strategies are implemented to investigate the role of the dam in the mitigation of the flood wave.

\subsection{Hydrological Data}

In the Upper Tiber River basin a real time hydro-meteorological network is operating. For this analysis, the data recorded during the heavy rainfall event occurred in November 2013 by 19 rain gauges (Figure 2) and three hydrometric gauges located at Pianello, Ponte Rosciano and in the reservoir were considered. During the whole event a rainfall depth equal to $\sim 330 \mathrm{~mm}$, with a return period approximately equal to 150-200 years, was registered in a couple of locations (e.g., Gualdo Tadino), which are located upstream of the dam, Table 1 . The rainfall event considered in the study started the 10th November 2013 at 12 a.m. and ended the 13rd November at 10 a.m. The hydrometric gauges recorded with a resolution of $30 \mathrm{~min}$ during the same time window.

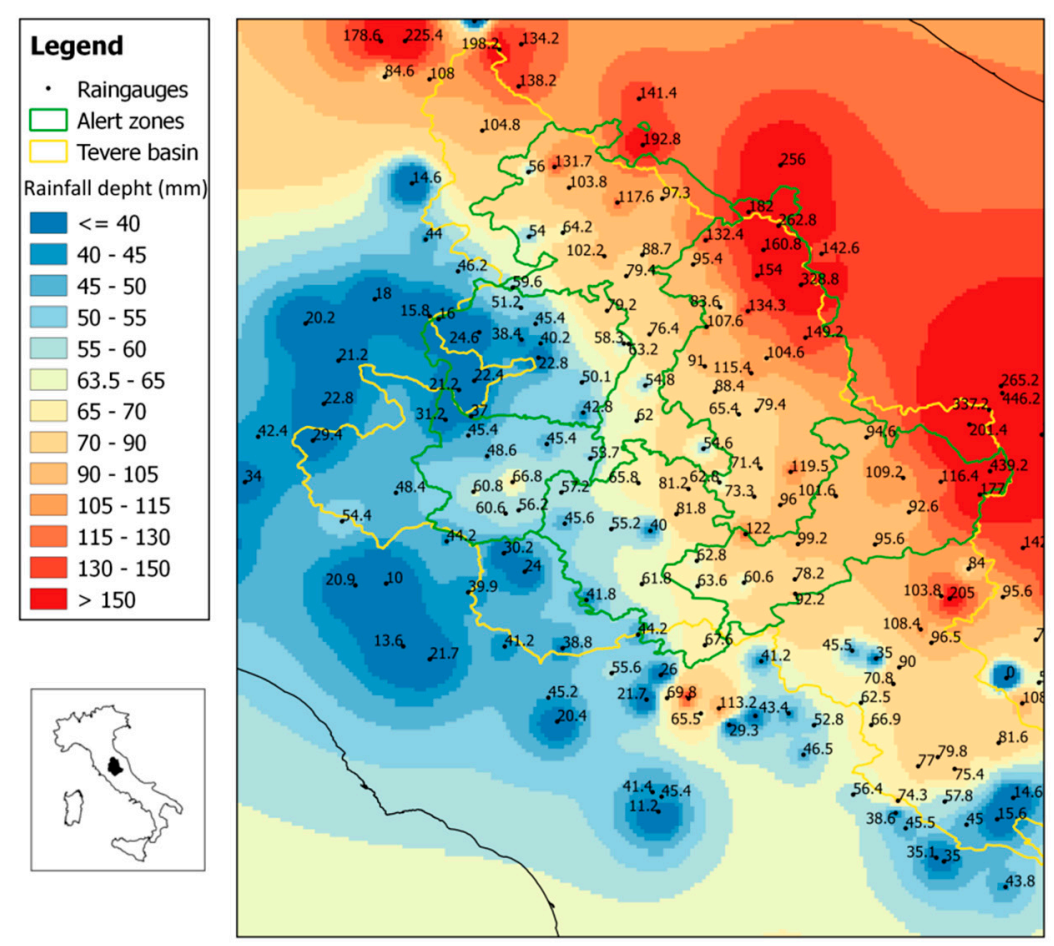

Figure 2. Localization of the rainfall event in the Umbria region, Italy (left panel); cumulated rainfall depth registered during the event occurred on November 2013 (right panel). 
Table 1. Rainfall depths registered at rain gauges for different time intervals during the flood event occurred on November 2013 in the Chiascio basin.

\begin{tabular}{|c|c|c|c|c|c|c|c|c|c|c|}
\hline \multirow{3}{*}{ Raingauges } & \multicolumn{10}{|c|}{ Rainfall Depth } \\
\hline & Total & $\begin{array}{c}\text { Max } \\
30 \mathrm{~min}\end{array}$ & $\begin{array}{c}\operatorname{Max} \\
1 \mathrm{~h}\end{array}$ & $\begin{array}{c}\text { Max } \\
3 \mathrm{~h}\end{array}$ & $\begin{array}{c}\text { Max } \\
6 \mathrm{~h}\end{array}$ & $\begin{array}{l}\text { Max } \\
12 \mathrm{~h}\end{array}$ & $\begin{array}{l}\text { Max } \\
24 \mathrm{~h}\end{array}$ & $\begin{array}{l}\text { Max } \\
36 \text { h }\end{array}$ & $\begin{array}{l}\text { Max } \\
48 \mathrm{~h}\end{array}$ & $\begin{array}{l}\text { Max } \\
72 \mathrm{~h}\end{array}$ \\
\hline & $(\mathrm{mm})$ & $(\mathrm{mm})$ & $(\mathrm{mm})$ & $(\mathrm{mm})$ & $(\mathrm{mm})$ & $(\mathrm{mm})$ & $(\mathrm{mm})$ & $(\mathrm{mm})$ & $(\mathrm{mm})$ & $(\mathrm{mm})$ \\
\hline Gualdo Tadino & 328.9 & 10.4 & 19.2 & 51 & 88.4 & 174.4 & 240.8 & 281.6 & 311.8 & 328.8 \\
\hline Monte Cucco & 262.9 & 10.1 & 19.9 & 44.6 & 73.2 & 124.8 & 184.1 & 217.8 & 248.4 & 262.8 \\
\hline Torre dell'Olmo & 161.1 & 7.6 & 14.2 & 33.2 & 50.6 & 96.6 & 130.6 & 153.4 & 157.8 & 160.8 \\
\hline Branca & 154.1 & 6.8 & 10.8 & 24.6 & 44.6 & 69.8 & 100 & 134.8 & 147.6 & 154 \\
\hline Nocera Umbra & 149.3 & 5.8 & 8.5 & 20.5 & 39.1 & 64.6 & 93.3 & 125.1 & 135.8 & 149.2 \\
\hline Casa Castalda & 134.4 & 8.4 & 12.9 & 24.7 & 35.3 & 60.6 & 99.9 & 122.9 & 129.1 & 134.3 \\
\hline Gubbio & 132.7 & 5.8 & 10.8 & 21.4 & 35.4 & 68 & 104 & 124.4 & 130.4 & 132.4 \\
\hline Azzano & 119.6 & 8.5 & 15.3 & 22.5 & 34.3 & 60.7 & 87.3 & 119.4 & 119.5 & 119.5 \\
\hline La Bolsella & 115.5 & 8.4 & 10.6 & 20 & 31 & 50 & 88.4 & 106.8 & 110.2 & 115.4 \\
\hline Pianello & 107.7 & 6.6 & 10.2 & 24.8 & 34.2 & 50.4 & 88 & 103 & 106 & 107.6 \\
\hline Armenzano & 104.7 & 8.2 & 12.4 & 27.2 & 33.6 & 45.2 & 73.2 & 96.6 & 99.4 & 104.6 \\
\hline Carestello Meteo & 96.1 & 5 & 9 & 20.2 & 33 & 43.2 & 77.6 & 90.8 & 94.6 & 95.4 \\
\hline Spoleto & 96.1 & 8 & 14.8 & 18.6 & 27.2 & 42.8 & 65.6 & 95.2 & 95.2 & 96 \\
\hline Bastia Umbra & 91.1 & 6 & 10.4 & 19 & 28.4 & 45.7 & 77.7 & 90.7 & 90.7 & 91 \\
\hline Cannara & 88.5 & 5.6 & 9.1 & 17.6 & 29.7 & 44.8 & 73.1 & 88.4 & 88.4 & 88.4 \\
\hline Casanuova & 83.7 & 6.2 & 9.8 & 22.6 & 32.6 & 38.8 & 64 & 80.6 & 82.8 & 83.6 \\
\hline Foligno & 79.5 & 8.7 & 11.4 & 18.5 & 25.2 & 36.1 & 65.4 & 79.3 & 79.4 & 79.4 \\
\hline La Bruna & 71.5 & 25.2 & 25.8 & 26.2 & 33 & 45.2 & 71.4 & 71.4 & 71.4 & 71.4 \\
\hline Bevagna & 65.5 & 10.4 & 12.2 & 18.4 & 26.8 & 33.4 & 54 & 65.4 & 65.4 & 65.4 \\
\hline
\end{tabular}

\section{Methodology: The Cascade Model}

To simulate the process of rainfall-runoff transformation and thus the hydrograph used as the dam input—a hydrological model was built. It was also used to simulate the different scenarios that represent the dam regulation strategies and therefore, to determine the corresponding output of the dam in terms of maximum discharge values. In turn, each output of the dam was used as an upstream boundary condition of the hydraulic model used to simulate the flood propagation and the inundation processes in the river reach. The hydraulic model was thus used to determine the effect, in terms of inundated areas, of each dam regulation scenario. In the following, both models will be detailed.

\subsection{The Hydrological Model}

The freely available semi-distributed event-based hydrological model HEC-HMS [21] was used for the analysis. Specifically, losses are estimated by using the Soil Conservation Service-Curve Number (SCS-CN), the SCS-Unit Hydrograph (SCS-UH) method represents the rainfall-runoff transformation, and the flood routing along the natural channels is simulated through the Muskingum-Cunge model.

As mentioned, losses are estimated by using the Soil Conservation Service-Curve Number (SCS-CN), whereby the direct runoff depth, $P_{e}$, is:

$$
P_{e}=\frac{\left(P-I_{a}\right)^{2}}{\left(P-I_{a}+S\right)}
$$

$P$ is the rainfall depth, $S$ is the potential maximum retention and $I_{a}$ is the initial abstraction, which can be expressed as a function of $S$. The SCS expressed $I_{a}=0.2 S$ on the basis of the results obtained for several experimental watersheds [22]. The potential maximum retention, $S$, is related to a dimensionless Curve Number $(\mathrm{CN})$ defined as a function of land use, soil type and antecedent wetness conditions (AWC).

The rainfall-runoff transformation is represented by using the SCS-Unit Hydrograph (SCS-UH) method incorporating only one parameter. This parameter is assumed to be the basin lag time, defined as the time shift between the centroids of effective rainfall and direct runoff [23]. Specifically, for each 
homogeneous elements (sub-basin), the lag time, $L$, is estimated by using the lag-area relationship proposed by [24]:

$$
L=\eta 1.19 A^{0.33}
$$

where $L$ is the basin lag time in hours, $A$ the drainage area in $\mathrm{km}^{2}$ and $\eta$ a parameter to be calibrated. Equation (2) with $\eta=1$ was obtained considering 26 watersheds in Central Italy with areas ranging from $12 \mathrm{~km}^{2}$ to $4147 \mathrm{~km}^{2}$. However, this result refers to the effective rainfall hyetographs determined by the extended form of the two-terms Philip's infiltration equation and the use of the geomorphological unit hydrograph for the rainfall-runoff transformation. Therefore, $\eta$ is considered here as a calibration parameter to take into account the differences due to the use of the SCS-CN method and the SCS unit hydrograph.

Finally, the flood routing along the natural channels is simulated through the Muskingum-Cunge model that is based on the combination of the conservation mass and the diffusion representation of the conservation of momentum. The coefficients are recalculated every time step as a function of channel properties and the flow depth.

The hydrological load of the hydraulic model is represented by the precipitation, gauged by the rain gauges deployed in the area of interest. The Inverse Distance Weight precipitation method is used to interpolate the rainfall across the area.

The dam behavior is modelled within the hydrological model. The reservoir is described by the elevation-storage relationship, which ensures the respect of the continuity equation, and by the characterization of a culvert outlet and a spillway.

Specifically, the outlet gate is characterized by a submerged inlet control and the discharge outflowing from the gate is given by:

$$
Q_{c}=C_{d} A_{c} \sqrt{2 g h}
$$

where $A_{c}$ is the area of the gate, which has a circular shape, $C_{d}$ is the discharge coefficient, $h$ is the total head.

While the discharge outflowing from the uncontrolled broad-crested spillway is given by:

$$
Q_{s}=C_{s} L H^{3 / 2}
$$

where $C_{S}$ is a variable coefficient of discharge, $L$ is the effective length of the crest, $H$ is the total head on the crest including velocity of approach head.

\section{Hydrological Model Calibration}

The rainfall-runoff model is calibrated using the flood event occurred in 2013, and the flood regulation strategy applied during that specific event. For this event, the hydrograph was available at two sites (i.e., Pianello and Ponte Rosciano) located downstream the dam. Specifically, Pianello is located around $10 \mathrm{~km}$ from the dam, while Ponte Rosciano is located in the proximity of the river outlet. During the event, the Casanuova dam, although not yet in full operation, allowed a partial regulation of the outflows playing a crucial role for the protection of the territories downstream, along the Chiascio River and avoiding the overlap between Tiber and Chiascio Rivers peak discharges. The dam is still not in full operation. Since we are investigating the extension of the flooded areas in a comparative framework, it is reasonable to calibrate the model using the event occurred in 2013 to predict the areas flooded by all management scenarios, simulating a full operating dam. The discharge outflowing during the event was always lower than $140 \mathrm{~m}^{3} / \mathrm{s}$, Figure 3, that represents the maximum discharge that flows in the downstream river reach without significant flooding. The dam retained $21 \mathrm{Mm}^{3}$ while the total inflow volume was $36 \mathrm{Mm}^{3}$.

It was not possible to know the evolution of the actual water level in the reservoir during the event because the hydrometer was broken, however the initial level in the reservoir was known and equaled 
$274 \mathrm{~m}$ a.s.l. Therefore, the calibration is performed comparing the peak discharge and the time to peak values simulated against those recorded at the two gauging stations (i.e., Pianello and Ponte Rosciano).

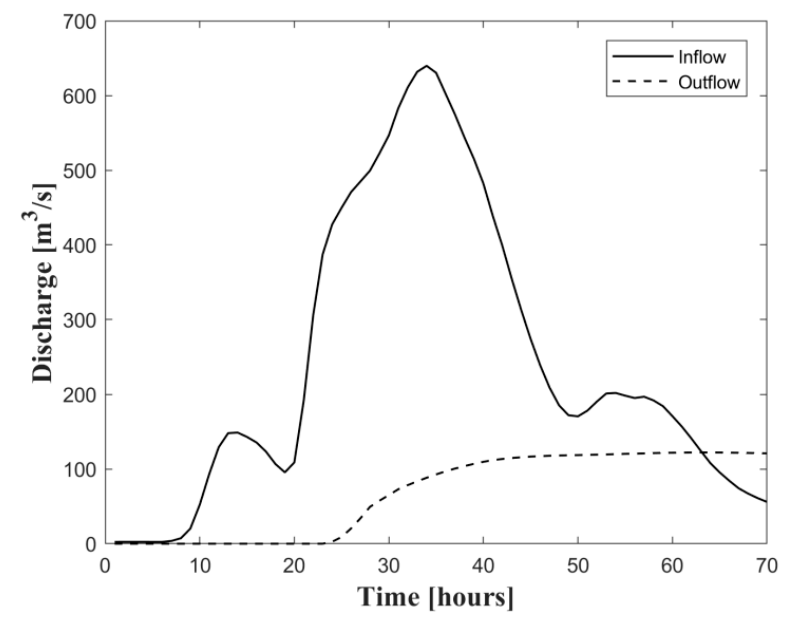

Figure 3. Inflow and outflow from the dam during the event occurred in 2013.

The estimation metrics that were used to calibrate the model are the following. The error between the peak values of the observed and simulated discharge is defined as:

$$
\varepsilon_{P}=\frac{\left(Q_{p, s i m}-Q_{p, o b s}\right)}{Q_{p, o b s}} 100
$$

where $Q_{p, \text { sim }}$ and $Q_{p, o b s}$ are the simulated and observed discharge peak values, respectively.

Then, the Nash Sutcliff Efficiency index (NSE) is estimated:

$$
\mathrm{NSE}=1-\frac{\sum_{j=1}^{N}\left(Q_{o b s, j}-Q_{s i m, j}\right)^{2}}{\sum_{j=1}^{N}\left(Q_{o b s, j}-\bar{Q}\right)^{2}},
$$

where $Q_{s i m, j}$ and $Q_{o b s, j}$ are the simulated and observed discharge values, respectively, at the time $j$ th for a total number of time steps $N$ equal to $71, \bar{Q}$ is the mean of observed discharge values. The Mean Absolute Error (MAE) is then estimated:

$$
\text { MAE }=\frac{\sum_{j=1}^{N}\left|Q_{o b s, j}-Q_{s i m, j}\right|}{N} .
$$

In Table 2 the values of the estimation metrics, together with the time to peak-that it is the time existing between the occurrence of the observed and the simulated flood peak, are shown

Table 2. Values of the estimation metrics used to calibrate the hydrological model: error between the peak values of the observed and simulated discharge $\left(\varepsilon_{\text {peak }}\right)$, the time to peak $\left(t_{\text {to peak }}\right)$, the Nash Sutcliff Efficiency index (NSE) and the Mean Absolute Error (MAE) at the two gauging stations of Pianello and Ponte Rosciano.

\begin{tabular}{ccccc}
\hline Gauge Station & $\begin{array}{c}\varepsilon_{\text {peak }} \\
(\mathbf{\%})\end{array}$ & $\begin{array}{c}\mathbf{t}_{\text {to peak }} \\
(\mathbf{h})\end{array}$ & $\begin{array}{c}\text { NSE } \\
-\end{array}$ & $\begin{array}{c}\text { MAE } \\
\left(\mathbf{m}^{3} / \mathbf{s}\right)\end{array}$ \\
\hline Pianello & -3 & -7 & 0.77 & 18.90 \\
Ponte Rosciano & 2 & 0 & 0.94 & 19.80 \\
\hline
\end{tabular}




\subsection{The Hydraulic Model}

The propagation in the channel of the discharge outflowing from the dam was performed using the one dimensional (1D) code HEC-RAS [25] in steady flow conditions. HEC-RAS has been widely applied for hydraulic modelling (e.g., [26-30]) and its trustworthy has been proven by many scholars (e.g., [31]).

Specifically, we employed the HEC-RAS software [25] to calculate the water depth and the flooded areas for different upstream boundary conditions corresponding to different outflow from the dam. The main idea is that not only the worst case scenario is worth being investigated, but also other management scenarios which may lead to minor floodings. The knowledge of the effects of diverse managements is required to enhance the risk mitigation and support the Civil Protection's action. The employed numerical modeling is based on one-dimensional steady flow. Energy losses are calculated through the Manning's equation and the momentum equation is solved in river cross-sections where the current is rapidly varied (e.g., at bridges, hydraulic jumps, and weirs). From the survey performed on site, 77 river-cross sections were extracted and used to build the river geometry, 11 hydraulic structures (i.e., bridges) were also surveyed and implemented in the model, Figure 4. We used the capabilities of the RAS Mapper routines, available directly in HEC-RAS to delineate the floodplain and generate inundation maps for all the available set of discharges deriving from the hydrological analysis [32]. A triangular interpolation surface is built from cross sections data and a detailed terrain model of the channel is created with a spatial resolution of $0.1 \mathrm{~m}$. The terrain model of the channel is then joined with a Digital Terrain Model (DTM) having a spatial resolution of $1 \mathrm{~m}$, as seen in Figure 5. Floodplain delineation results are achieved by applying the water surface elevations computed by the hydraulic model to the interpolation surface. The water surface elevation is converted to a grid and compared with the ground surface to create a continuous depth surface. As boundary conditions, discharge values are imposed at the inlet, at river cross-sections corresponding to the town of Petrignano, to Ponte Rosciano and to the confluence of both Tescio and Topino Rivers. As a downstream boundary condition, a known water surface elevation is given, which represents the water depth in correspondence of the junction with the Tiber River. The model was calibrated against PAI flood inundation maps [33].

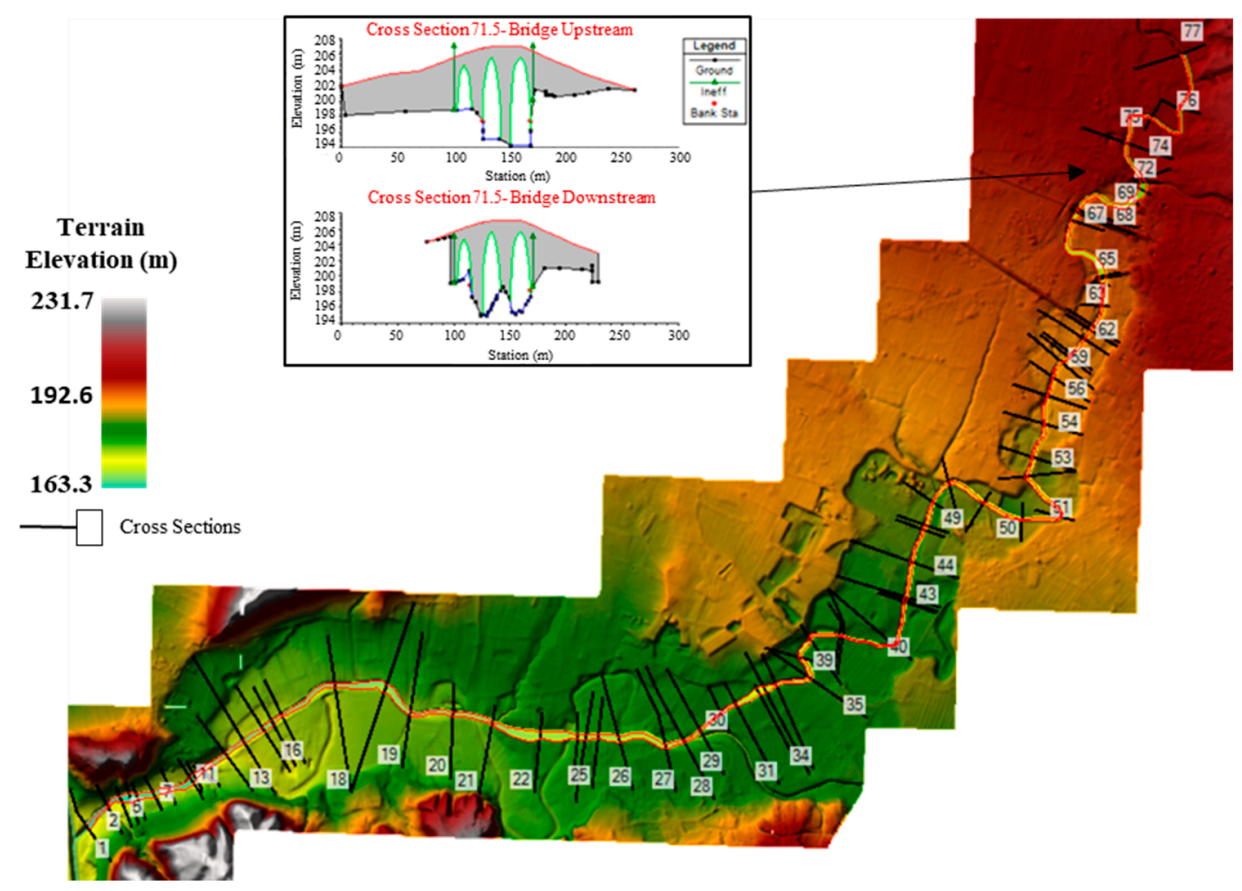

Figure 4. Hydraulic model built with HEC-RAS. The 77 river cross-sections, panel below and a schematized picture of a bridge, panel above. 


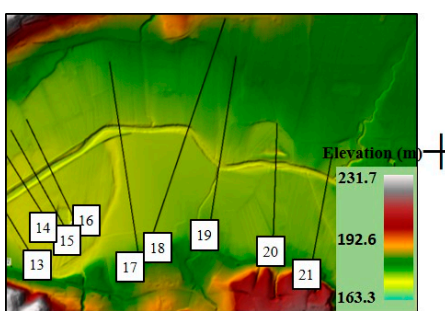

LIDAR-DTM Umbria Region

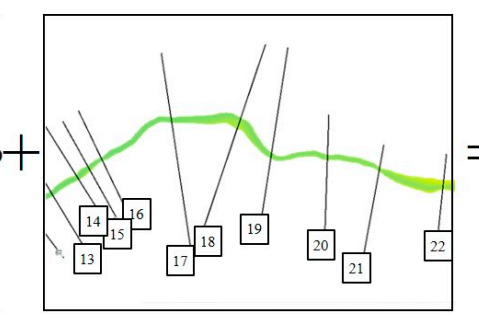

Built DTM Chiascio Channel

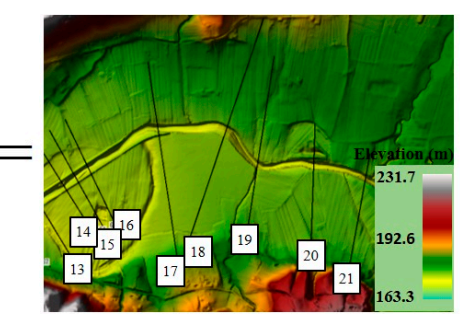

DTM for the case study

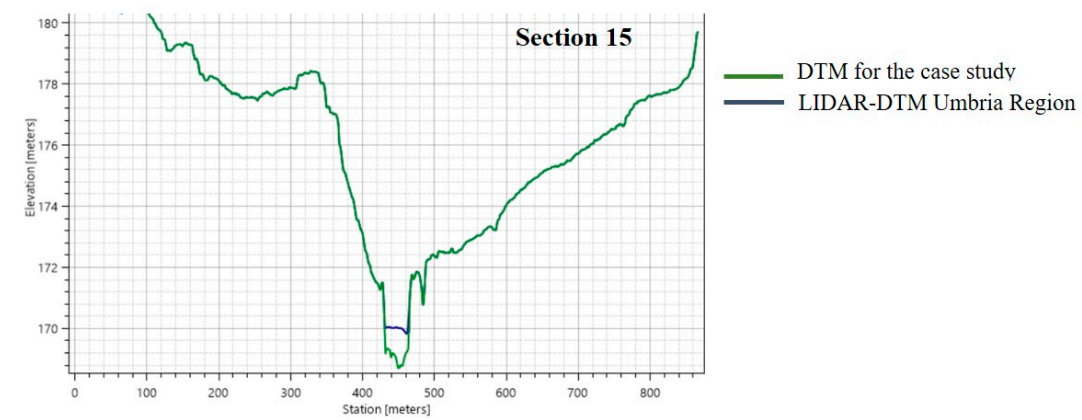

Figure 5. Construction scheme of the detailed terrain model.

\subsection{Flood Inundation Maps}

Flood inundation maps can be generated through deterministic or probabilistic approaches (e.g., [34,35]). Deterministic approaches are based on the assumption that the hydraulic model can fully represent the physical behavior of the river. To this end, usually the most physically realistic and most computationally affordable model is chosen. Once the model is calibrated, the map obtained is considered as truth [36]. On the other hand, probabilistic approaches are based on ensemble simulations. Specifically, a Monte Carlo approach is implemented, thus a large number of simulations is performed, taking into account hydrological uncertainty corresponding to the magnitude of a specific flood event. The probabilistic map is then drawn by executing a weighted sum of each Monte Carlo simulation at each $i$ th cell of the Digital Elevation Model [37]. The probabilistic approach relies on the assumption that all flood inundation maps have the same probability of occurrence.

In this case, the flood inundation maps do not have the same probability, as they are not generated from equally probable scenarios, thus it is not possible to retrieve a probabilistic flood inundation map. However, we aimed at understanding which are the areas that are more prone to be hit by the flood events using a frequentist approach. To this end, we built an ensemble of all flood maps (i.e., 360) derived by the model assigning to each $i$ th cell a value depending to whether the cell was flooded or not. Then, the flood state is given according to the frequentist approach:

$$
\mathrm{C}_{\mathrm{i}}=\frac{\sum_{\mathrm{k}} \mathrm{w}_{\mathrm{ki}}}{\mathrm{M}}
$$

where $\mathrm{w}$ is either 1 for a wet cell or 0 for a dry cell and $\mathrm{M}$ is the number of scenarios (i.e., 360). A cell is considered wet when the water depth in the cell is higher than $0.2 \mathrm{~m}$ [38].

\section{Results}

To estimate the effect of a flood event on the river reach and on the floodplain downstream the dam, first the hydrological model is run. The hydrological model allowed us to transform the heavy rainfall event characterized by a return period of 200 years into runoff. The resulting flood wave has a peak of $640 \mathrm{~m}^{3} / \mathrm{s}$ and is used as a forcer to the dam. The dam behavior is represented within the hydrological model, obtaining as output of the model the discharge values outflowing from the dam corresponding to different regulation strategies. These discharge values are used as input of the 
hydraulic model to generate the corresponding flood inundation maps. Then, a flood map envelope is estimated as indicated by Equation (8), Figure 6. The envelope allowed us to understand the effect of different operation rules on the floodplain downstream the dam. A historical flood event has been used because of its characteristics of magnitude and because it was of great interest to investigate how different management strategies would have coped with the incoming flood wave.

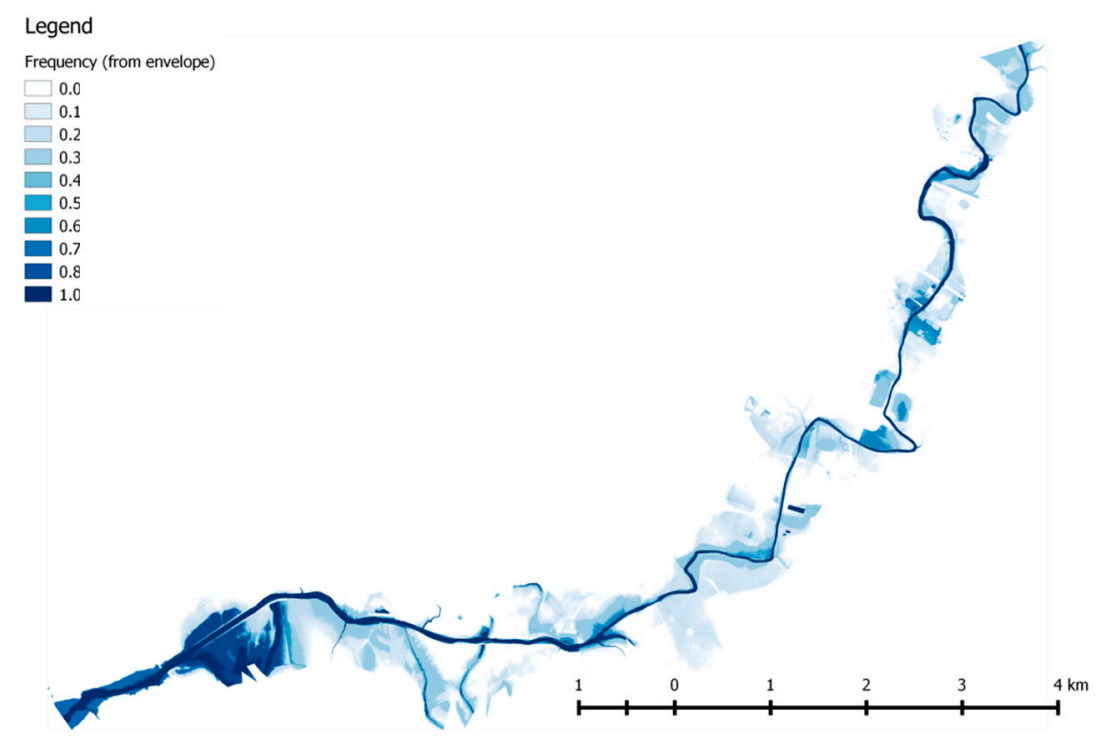

Figure 6. Flood map envelope. The frequency of each cell to be flooded is presented in color ranging from white (i.e., 0) to dark blue (i.e., 1).

As the purpose of the Casanuova dam is to cope with both hydrological extreme events (i.e., floods and droughts), the management scenarios have to represent these two conflicting interests. On one side, the dam has to furnish water for irrigation purposes and provide drinking water. This is specifically relevant when a drought event happens and thus the settlements largely rely on the capacity of the dam retention basin. On the other side, the dam is used to mitigate the incoming flood waves to protect the settlements downstream. These two conflicting interests result in conflicting scenarios of dam operation strategies. On one side, the reservoir must be kept as full as possible to provide water to the surrounding settlements and to industrial and agricultural activities. On the other side, the water level in the reservoir should be close to its minimum value to allow a suitable reduction of extreme flood waves. The envelope map has thus the purpose to show the areas that would be more affected by these two conflicting interests that drive the operation strategies of the dam. Since many settlements and productive activities are located along the river reach, this results also from the envelope map. The knowledge of the residual risk associated to the presence of the dam is of utmost importance to plan non-structural flood risk mitigation strategies, such as early warning systems. Moreover, it allows the Civil Protection to plan effective projects to raise the awareness of the population living in flood prone areas in order to increase its preparedness to face a flood event.

Since the interest in the dam operation strategies, it is important to understand which is their impact on the reduction of the flood wave. To this end, the plot in Figure 7 shows the value of the discharge outflowing from the dam against the different initial water level in the reservoir for different openings of the outlet gate. When the initial level equals its maximum value (i.e., $330 \mathrm{~m}$ a.s.l.), both the spillway and the gate work. Thus, the water discharged is the sum of the contribution of the two release structures. The spillway releases water as a function of the total head on the spillway crest at the power of $3 / 2$, while the culvert releases water with a law function of the squared value of the water depth in the reservoir (i.e., Equations (3) and (4)). Thus, the contribution of the spillway significantly affects the discharge released by the structure. The highest value of released discharge is due to a fully opened culvert for any value of the initial level in the reservoir. The superposition of the discharges 
released by the two types of outlets should be avoided. When the water level in the reservoir is higher than $325 \mathrm{~m}$ a.s.l., the gate should be half open, while, if the water level is lower than $325 \mathrm{~m}$ a.s.l., the gate should be closed, as seen in Figure 7.

We also reported the ratio between the outflow and the maximum outflow, as seen in Figure 7.

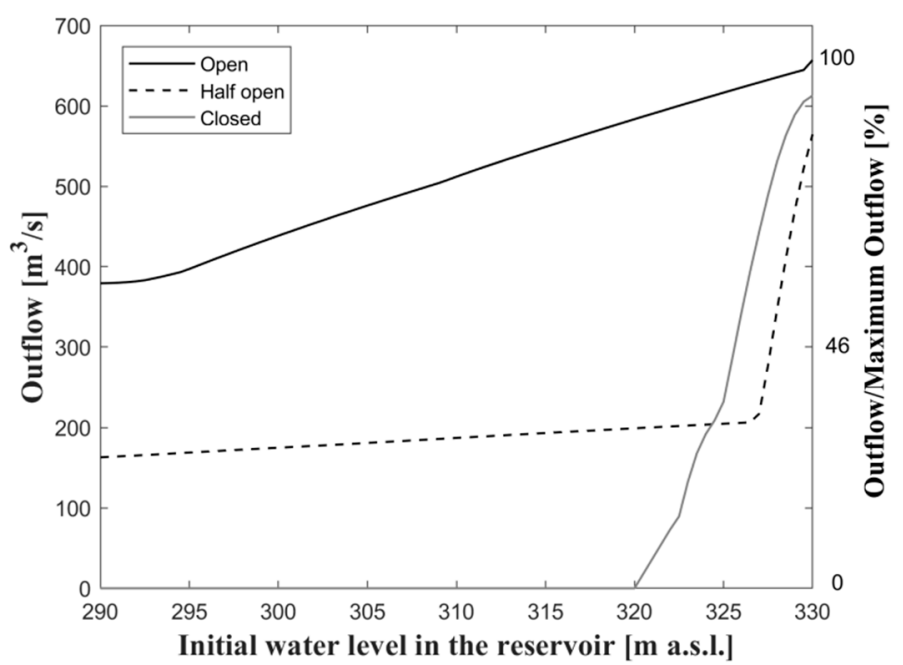

Figure 7. Discharge outflowing from the dam in absolute value (left axis) against the initial level in the reservoir for the three opening of the outlet gate (i.e., open, half open and closed). The outflow is compared with the maximum possible outflow and the value is reported in percentage (right axis).

As expected, while the reduction of the flood peak is small when the initial level in the reservoir is high, the capacity of lessening the discharge released downstream is higher when the initial level is low. However, the opening of the culvert plays a major role, in the case of a wide open culvert. The maximum discharge outflows when the retention basin is full and the culvert is wide open. With a wide open culvert, the reduction of the outflow can be at most the $40 \%$ of the maximum outflowing discharge (i.e., around $400 \mathrm{~m}^{3} / \mathrm{s}$ when the water elevation in the reservoir is $290 \mathrm{~m}$ a.s.l.), while there is a substantial reduction in the other two cases.

We report the flood inundation maps of the three worst case scenarios for the three different openings (i.e., corresponding to a full reservoir), Figure 8.

The case of the half-open outlet gate may look more optimistic, as the discharge outflowing is the smallest among all the cases, Figure 9 and Table 3. This may result also looking at a detail of the flood inundation maps, Figure 10, where an industrial area in the city of Bastia is shown. The two conditions of closed and open gate are very similar, while the half open case shows the smallest flooded area. 


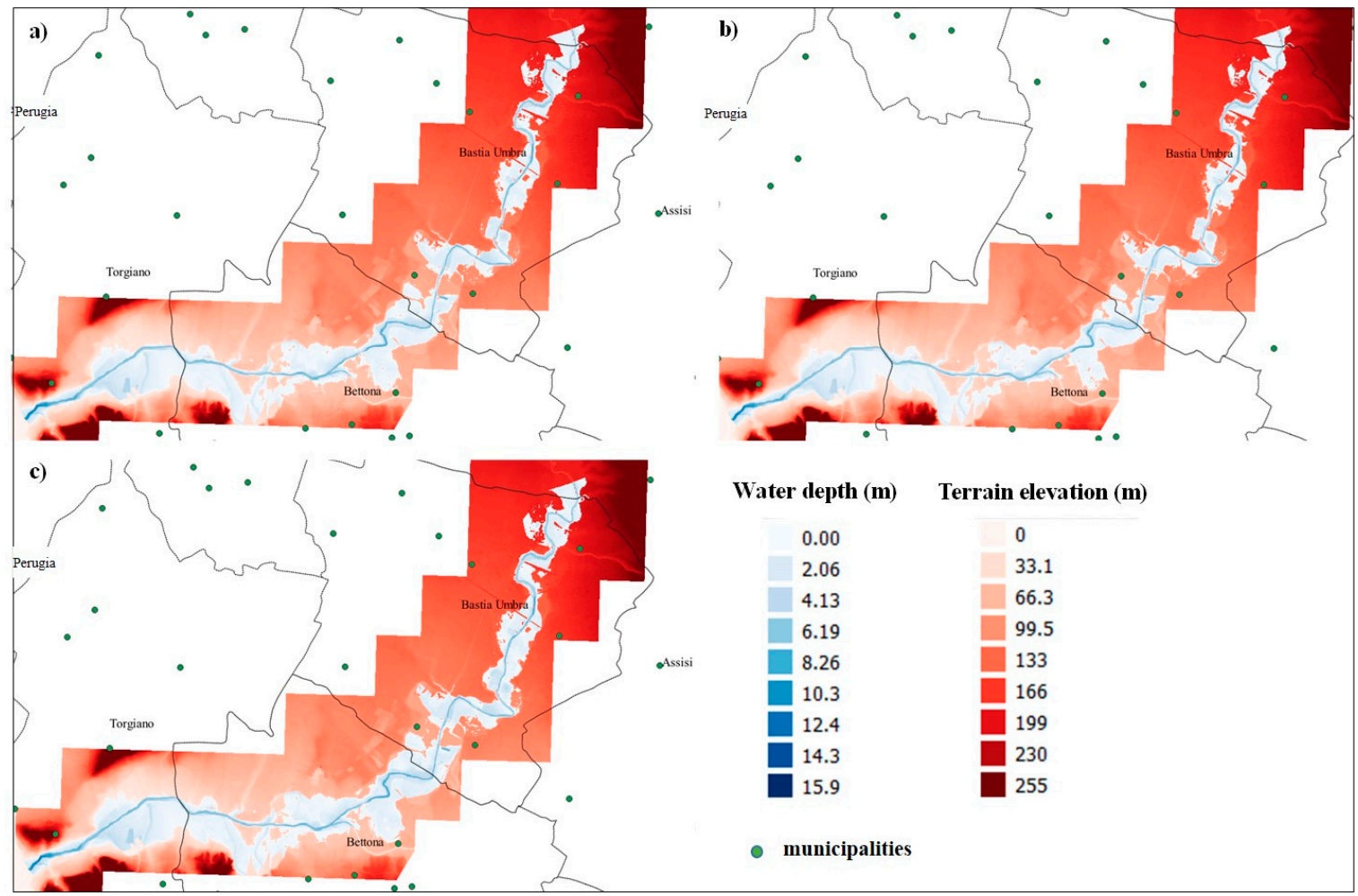

Figure 8. Three maps of the flooded area generated considering the initial water level in the reservoir equals to its maximum value (330 $\mathrm{m}$ a.s.l.) and for the three different opening of the outlet gate: closed (panel a), half open (panel b), open (panel c).

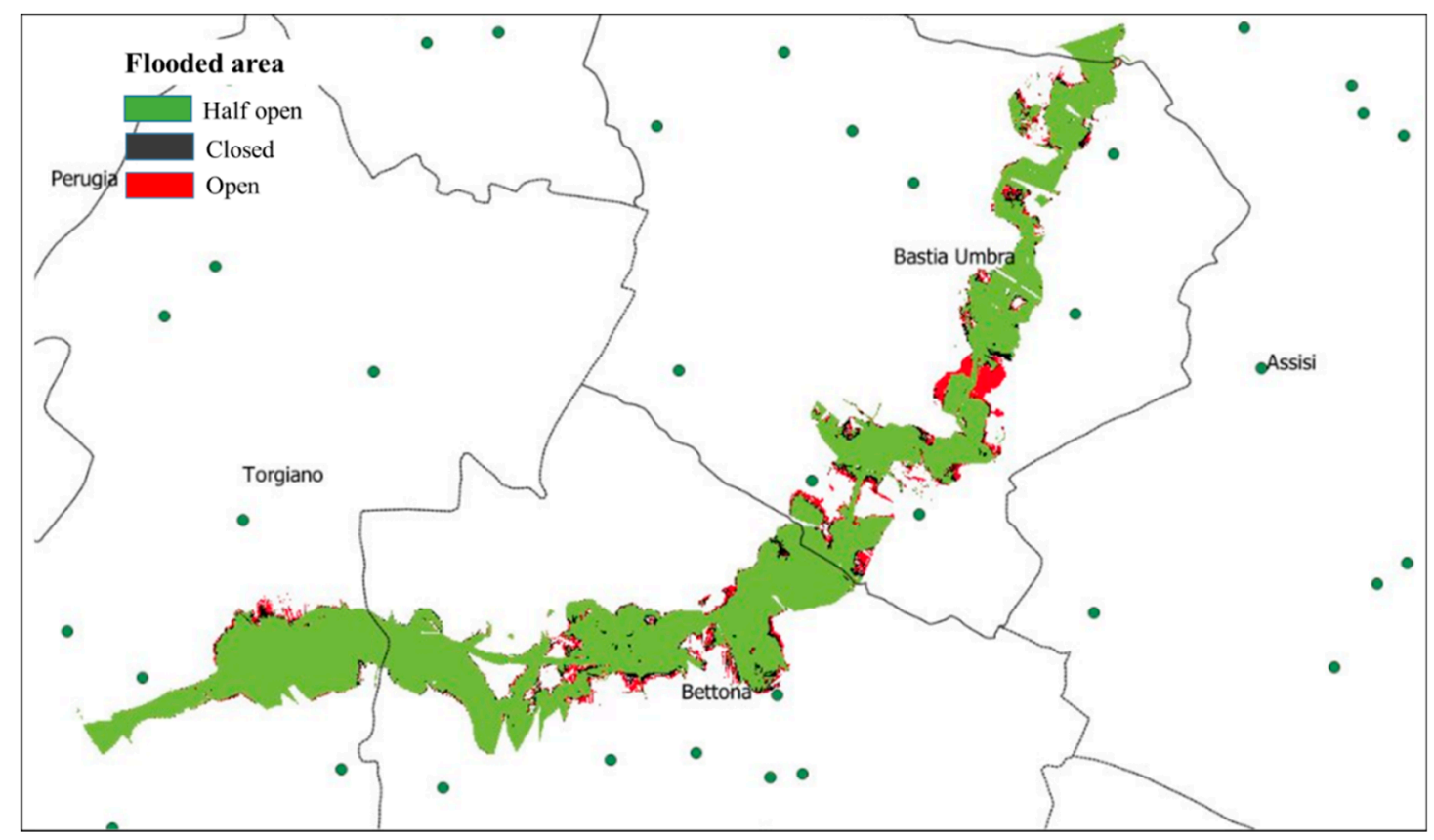

Figure 9. Overlap of the three flood inundation maps obtained with the three different openings of the culvert and setting the initial level in the reservoir equal to its maximum value (i.e., $330 \mathrm{~m}$ a.s.l.). 
Table 3. Characteristics of the flood area downstream of Pianello, the initial water level in the reservoir is equal to $330 \mathrm{~m}$ a.s.l.

\begin{tabular}{cccc}
\hline & \multicolumn{3}{c}{ Outlet Gate } \\
\cline { 2 - 4 } & Closed & Half Open & Open \\
\hline Flooded Aea $\left(\mathrm{km}^{2}\right)$ & 7.37 & 6.82 & 7.93 \\
$\mathrm{~h}_{\text {mean }}(\mathrm{m})$ & 1.58 & 1.46 & 1.52 \\
\hline
\end{tabular}

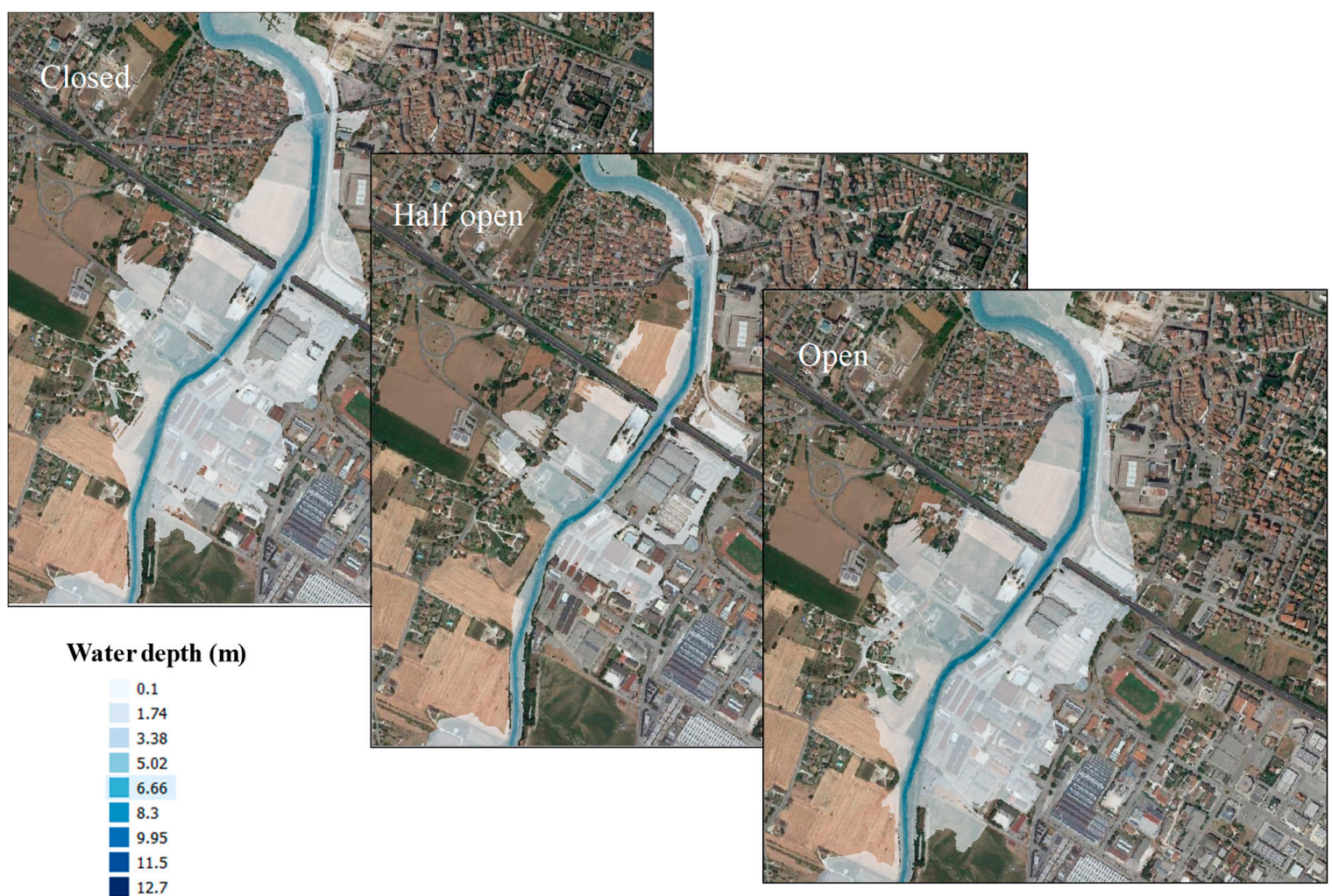

Figure 10. Three details of a flooded area for three different opening of the outlet gate (in the box on each panel) generated considering a water level in the reservoir equals to its maximum value.

However, it is noteworthy to bear in mind that the half open case is the best until the level in the reservoir makes the spillway crest working, otherwise the best is the case "closed" outlet gate.

Results show that the spillway crest has a crucial role as its impact on the released discharge is much higher than the one of the outlet gate. However, it is also worth noting that the opening of the outlet gate plays a major role for any water depth, especially when it is fully open.

In this study, the overtopping and the possible breach of the levee systems were not simulated. Since the importance of the interaction between flood scenarios and levees, we encourage future research to complement this work and thus study the effects of levee failures on the floodplain.

\section{Discussion}

The knowledge of the discharge released downstream when an extreme flood event occurs is of utmost importance to understand its impact on the floodplain. The dam may insinuate a false sense of safety in the citizens living in the areas that were originally at risk. As investigated by several scholars, hydraulic structures, such as levee systems and dams, may fade the memory of locals which forget to be in a flood prone area and engage themselves in activities that do not cope well with hydrological extremes (e.g., [9,39]). As a matter of fact, these structures alter the frequency, the magnitude, and spatial distribution of hydrological extreme events $[3,40,41]$. Dams and reservoirs are examples of structures that change hydrological behavior of a catchment and significantly change hydrological extremes 
(i.e., both flood events and droughts [42]). Therefore, the construction of structural risk mitigation strategies may shape the risk perception in the local community as in the case of the Brisbane dam which led to consider the namesake city as flood proof, until the catastrophic event occurred in 2011 [43].

In this framework, it is crucial to understand which would be the effect of an extreme flood event on the floodplain-located downstream of the dam. Since the dam plays a major role in altering the flood event, it is important to analyze different scenarios of dam management strategies to understand the impact that these scenarios would have on the flood event. To this end, in this paper, we analyzed a large number of management scenarios which depend on the combination of the initial water level in the reservoir and the opening of the outlet gate. It resulted in the implementation of a flood maps envelope that indicates the areas more exposed to flood risk. This flood risk can also be called residual risk, as it is a consequence of the dam presence and needs to be mitigated using structural and non-structural methodologies. Structural measures comprise the construction or heightening of a levee system, while non-structural measures can be the introduction of policies and laws, public awareness raising, training and education to reduce risks and impacts [44,45]. The choice of relying on one type of mitigation measure rather than another one can be due to the type of society settled on the floodplain [46] or to the existence of structural measures that were built before the construction of the retention basin. The latter is the case of the case study area, where structural devices were set in place before the erection of the dam. Thus, the knowledge of the residual risk on the floodplain is vital to implement measures which could raise the awareness in the population.

\section{Conclusions}

This paper aimed at exploring how flood inundation patterns are altered by the presence of a multi-purpose dam or a retention basin. Since the dam under study was built to mitigate both floods and droughts, we hypothesized that the management of the dam was focused both on the mitigation of droughts and floods. To this end, we assumed that the water level in the reservoir could have assumed any value from its minimum to its maximum before the arrival of the flood wave. We combined the water level in the reservoir with different openings of the outlet gate that discharges the water downstream. The discharge outflowing from the dam has then be used to determine flood inundation maps in the floodplain located downstream of the dam.

This allowed us to explore how diverse dam operation strategies may alter the flood event with different impacts on the downstream floodplain areas. Since the dam was built to provide water supply for irrigation and drinkable purposes, the reservoir may be full before the occurrence of a flood event. In this framework it is crucial to understand the behavior of the dam and which operation strategy could cope better with the variety of scenarios that may occur.

In the case of the Casanuova dam, when the water level in the reservoir equals its maximum level, both the spillway crest and the outlet gate work. This results in a large release of discharge, which inundates the floodplain downstream. If the outlet gate is fully open, the resulting scenarios are the worst compared to a half-open and closed gate as the outflowing discharge is a function of the water depth in the reservoir. In contrast, the best scenario is represented by the combination of a low water level in the reservoir and a small opening of the outlet gate.

The knowledge of the effect of the regulation strategies of the dam in terms of flood inundation maps is of utmost importance to plan mitigation projects and actions to raise citizens' awareness. The flood inundation maps envelope resulting from this study can be used by the Civil Protection to estimate the residual risk in floodplain areas, plan evacuation routes, and implement effective strategies to safeguard settlements and productive areas located along the river reach in flood prone areas. Moreover, the Civil Protection may improve the maps of municipal emergency planning with the crucial support of the Local Functional Center network, which supports the national alerting system at regional scale (e.g., managing the provisional phase and the monitoring and control during the event, ensuring the data flow to the civil protection for the emergency and the management of the emergency). 
Flood hazard investigations are often based on three different types of flooding with low, medium and high probability of occurrence, corresponding to a return period lower than or equal to 500, 100-200 and 20-50 years, respectively. The flood inundation maps could allow a new perspective focused on the introduction of an additional "residual flood hazard zone" and could lead to the adaptive management strategies to evaluate the effectiveness and the benefits of particular risk management options based on the concept of residual risks.

Finally, the outcomes of the present study may also allow a fair communication of flood risks to the general public, by clarifying that a residual risk is always present after the implementation of any protection measure.

A future perspective of this work is the analysis of how people living in these flood prone areas respond to the effects of the hydrological extremes. As a matter of fact, there is still little understanding of how communities adapt and cope with hydrological extremes influenced by reservoir management [1]. In particular, the concept of risk perception [47-49], as the result of intuitive biases, economic interests and cultural values, should be considered, by taking into account death rates and other factors, as emotions (i.e., outrage; [50]). This is part of a wider research agenda in the framework of the "Panta Rhei", the upcoming IAHS Scientific Decade [18], which aims to uncover the mutual shaping of hydrology and society.

Author Contributions: Conceptualization, E.R. and P.M.; methodology, E.R. and P.M.; software, E.R., C.P. and S.D.F.; formal analysis and investigation, all authors; data curation, C.P. and N.B.; writing-original draft preparation, E.R.; writing — review and editing, E.R., C.P. and S.D.F.; supervision, E.R., C.B., N.B. and P.M.

Funding: This work was partially supported by the Italian Ministry of Education, University and Research under the PRIN grant No.20154EHYW9 "Combined numerical and experimental methodology for fluid structure interaction in free surface flows under impulsive loading".

Acknowledgments: The authors would like to thank Giuliano Di Baldassarre for the fruitful discussion on an early version of the paper and Claudio Mineo for the support with GIS. Two Anonymous Reviewers are also acknowledged for constructive comments to this paper.

Conflicts of Interest: The authors declare no conflict of interest. The funders had no role in the design of the study; in the collection, analyses, or interpretation of data; in the writing of the manuscript, or in the decision to publish the results.

\section{References}

1. Di Baldassarre, G.; Martinez, F.; Kalantari, Z.; Viglione, A. Drought and flood in the Anthropocene: Feedback mechanisms in reservoir operation. Earth Syst. Dyn. 2017, 8, 225-233. [CrossRef]

2. White, G.F. Human Adjustments to Floods; Department of Geography Research Paper No. 29; Department of Geography: Chicago, IL, USA, 1945.

3. Di Baldassarre, G.; Wanders, N.; AghaKouchak, A.; Kuil, L.; Rangecroft, S.; Veldkamp, T.I.E.; Garcia, M.; van Oel, P.R.; Breinl, K.; Van Loon, A.F. Water shortages worsened by reservoir effects. Nat. Sustain. 2018, 1,617-622. [CrossRef]

4. Ullberg, S.B. Forgetting Flooding?: Post-disaster Livelihood and Embedded Remembrance in Suburban Santa Fe, Argentina. Nat. Cult. 2018, 13, 27-45. [CrossRef]

5. Scolobig, A.; Pellizzoni, L.; Bianchizza, C. Public Participation and Trade-Offs in Flood Risk Mitigation: Evidence from Two Case Studies in the Alps. Nat. Cult. 2016, 11, 93-118. [CrossRef]

6. Scolobig, A.; De Marchi, B.; Borga, M. The missing link between flood risk awareness and preparedness: Findings from case studies in an Alpine. Nat. Hazards 2012, 63, 499-520. [CrossRef]

7. Molinari, D.; Menoni, S.; Aronica, G.T.; Ballio, F.; Berni, N.; Pandolfo, C.; Stelluti, M.; Minucci, G. Ex post damage assessment: An Italian experience. Nat. Hazards Earth Syst. Sci. 2014, 14, 901-916. [CrossRef]

8. Dessai, S.; Sims, C. Public perception of drought and climate change in southeast england. Environ. Hazards 2010, 9, 340-357. [CrossRef]

9. Di Baldassarre, G.; Viglione, A.; Carr, G.; Kuil, L.; Salinas, J.L.; Blöschl, G. Socio-hydrology: Conceptualising human-flood interactions. Hydrol. Earth Syst. Sci. 2013, 17, 3295-3303. [CrossRef]

10. Briscoe, J. Water security: Why it matters and what to do about it. Innov. Technol. Gov. Glob. 2009, 4, 3-28. [CrossRef] 
11. Ridolfi, E.; Manciola, P. Water Level Measurements from Drones: A Pilot Case Study at a Dam Site. Water 2018, 10, 297. [CrossRef]

12. Bizzi, S.; Pianosi, F.; Soncini-Sessa, R. Valuing hydrological alteration in multi-objective water resources management. J. Hydrol. 2012, 472-473, 277-286. [CrossRef]

13. Bruno, M.C.; Siviglia, A. Assessing impacts of dam operations-interdisciplinary approaches for sustainable regulated river management. River Res. Appl. 2012, 28, 675-677. [CrossRef]

14. Richter, B.D.; Thomas, G.A. Restoring environmental flows by modifying dam operations. Ecol. Soc. 2007, 12, 12. [CrossRef]

15. Biscarini, C.; Di Francesco, S.; Ridolfi, E.; Manciola, P. On the simulation of floods in a narrow bending valley: The malpasset dam break case study. Water (Switzerland) 2016, 8, 545. [CrossRef]

16. van den Honert, R.C.; McAneney, J. The 2011 Brisbane Floods: Causes, Impacts and Implications. Water 2011, 3, 1149-1173. [CrossRef]

17. Apel, H.; Aronica, G.T.; Kreibich, H.; Thieken, A.H. Flood risk analyses-How detailed do we need to be? Nat. Hazards 2009, 49, 79-98. [CrossRef]

18. Montanari, A.; Young, G.; Savenije, H.H.G.; Hughes, D.; Wagener, T.; Ren, L.L.; Koutsoyiannis, D.; Cudennec, C.; Toth, E.; Grimaldi, S.; et al. "Panta Rhei-Everything Flows": Change in hydrology and society-The IAHS Scientific Decade 2013-2022. Hydrol. Sci. J. 2013, 58, 1256-1275. [CrossRef]

19. Ridolfi, E.; Montesarchio, V.; Rianna, M.; Sebastianelli, S.; Russo, F.; Napolitano, F. Evaluation of rainfall thresholds through entropy: Influence of bivariate distribution selection. Irrig. Drain. 2013, 62. [CrossRef]

20. Montesarchio, V.; Napolitano, F.; Rianna, M.; Ridolfi, E.; Russo, F.; Sebastianelli, S. Comparison of methodologies for flood rainfall thresholds estimation. Nat. Hazards 2015, 75, 909-934. [CrossRef]

21. HEC. Hydrologic Engineering Center, Hydrologic Modeling System (HEC-HMS): User's Manual 4.2; U.S. Army Corps of Engineers: Davis, CA, USA, 2016.

22. Ponce, V.M.; Hawkins, R.H. Runoff Curve Number: Has it reached maturity? J. Hydrol. Eng. 1996, 1, 11-19. [CrossRef]

23. Singh, V.P. Derivation of surface water lag time for converging overland flow. J. Am. Water Resour. Assoc. 1975, 11, 505-513. [CrossRef]

24. Melone, F.; Corradini, C.; Singh, V.P. Lag prediction in ungauged basins: An investigation through actual data of the upper Tiber River valley. Hydrol. Process. 2002, 16, 1085-1094. [CrossRef]

25. HEC. Hydrologic Engineering Center, Hydraulic Reference Manual; US Army Corps of Engineers: Davis, CA, USA, 2016.

26. Di Baldassarre, G.; Castellarin, A.; Montanari, A.; Brath, A. Probability-weighted hazard maps for comparing different flood risk management strategies: A case study. Nat. Hazards 2009, 50, 479-496. [CrossRef]

27. Brandimarte, L.; Di Baldassarre, G. Uncertainty in design flood profiles derived by hydraulic modelling. Hydrol. Res. 2012, 43, 753-761. [CrossRef]

28. Ridolfi, E.; Alfonso, L.; Di Baldassarre, G.; Dottori, F.; Russo, F.; Napolitano, F. An entropy approach for the optimization of cross-section spacing for river modelling. Hydrol. Sci. J. 2014, 59, 126-137. [CrossRef]

29. Manciola, P.; Di Francesco, S.; Biscarini, C. Flood protection and risk management: The case of Tescio River basin. IAHS-AISH Publ. 2009, 327, 174-183.

30. Di Francesco, S.; Biscarini, C.; Manciola, P. Characterization of a Flood Event through a Sediment Analysis: The Tescio River Case Study. Water 2016, 8, 308. [CrossRef]

31. Horritt, M.S.; Bates, P.D. Evaluation of $1 \mathrm{D}$ and 2D numerical models for predicting river flood inundation. J. Hydrol. 2002, 268, 87-99. [CrossRef]

32. Ackerman, C.T.; Jensen, M.R.; Brunner, G.W. Geospatial capabilities of HEC-RAS for model development and mapping. In Proceedings of the 2nd Joint Federal Interagency Conference, Las Vegas, NV, USA, 27 June-1 July 2010; Hydrologic Engineering Center, Institute for Water Resources, U.S. Corps of Engineers: Davis, CA, USA, 2010.

33. ABT Autorità di Bacino del Fiume Tevere. Piano Stralcio di Assetto Idrogeologico. Approvato con DPCM del 10 Novembre 2006. Available online: http://www.abtevere.it/ (accessed on 13 February 2019).

34. Horritt, M.S. A methodology for the validation of uncertain flood inundation models. J. Hydrol. 2006, 326, 153-165. [CrossRef] 
35. Merz, B.; Thieken, A.H.; Gocht, M. Flood Risk Mapping At The Local Scale: Concepts and Challenges. In Flood Risk Management in Europe: Innovation in Policy and Practice; Begum, S., Stive, M.J.F., Hall, J.W., Eds.; Springer: Dordrecht, The Netherlands, 2007; pp. 231-251.

36. Di Baldassarre, G.; Schumann, G.; Bates, P.D.; Freer, J.E.; Beven, K.J. Flood-plain mapping: A critical discussion of deterministic and probabilistic approaches. Hydrol. Sci. J. 2010, 55, 364-376. [CrossRef]

37. Alfonso, L.; Mukolwe, M.M.; Di Baldassarre, G. Probabilistic Flood Maps to support decision-making: Mapping the Value of Information. Water Resour. Res. 2016, 52, 1026-1043. [CrossRef]

38. Ridolfi, E.; Yan, K.; Alfonso, L.; Di Baldassarre, G.; Napolitano, F.; Russo, F.; Bates, P.D. An entropy method for floodplain monitoring network design. AIP Conf. Proc. 2012, 1479, 1780-1783.

39. Di Baldassarre, G.; Kreibich, H.; Vorogushyn, S.; Aerts, J.; Arnbjerg-Nielsen, K.; Barendrecht, M.; Bates, P.; Borga, M.; Botzen, W.; Bubeck, P.; et al. Hess Opinions: An interdisciplinary research agenda to explore the unintended consequences of structural flood protection. Hydrol. Earth Syst. Sci. Discuss. 2018, 22, 5629-5637. [CrossRef]

40. AghaKouchak, A.; Feldman, D.; Hoerling, M.; Huxman, T.; Lund, J. Water and climate: Recognize anthropogenic drought. Nature 2015, 524, 409-411. [CrossRef] [PubMed]

41. Van Loon, A.F.; Gleeson, T.; Clark, J.; Van Dijk, A.I.J.M.; Stahl, K.; Hannaford, J.; Di Baldassarre, G.; Teuling, A.J.; Tallaksen, L.M.; Uijlenhoet, R.; et al. Drought in the Anthropocene. Nat. Geosci. 2016, 9, 89-91. [CrossRef]

42. Ye, B.; Yang, D.; Kane, D.L. Changes in Lena River streamflow hydrology: Human impacts versus natural variations. Water Resour. Res. 2003, 39, 1200. [CrossRef]

43. Bohensky, E.L.; Leitch, A.M. Framing the flood: A media analysis of themes of resilience in the 2011 Brisbane flood. Reg. Environ. Chang. 2014, 14, 475-488. [CrossRef]

44. UNISDR. Terminology on Disaster Risk Reduction United Nations International Strategy for Disaster Reduction; UNISDR: Geneva, Switzerland, 2009.

45. Dawson, R.J.; Ball, T.; Werritty, J.; Werritty, A.; Hall, J.W.; Roche, N. Assessing the effectiveness of non-structural flood management measures in the Thames Estuary under conditions of socio-economic and environmental change. Glob. Environ. Chang. 2011, 21, 628-646. [CrossRef]

46. Ciullo, A.; Viglione, A.; Castellarin, A.; Crisci, M.; Di Baldassarre, G. Socio-hydrological modelling of flood-risk dynamics: Comparing the resilience of green and technological systems. Hydrol. Sci. J. 2017, 62, 880-891. [CrossRef]

47. Slovic, P.; Weber, E.U. Perception of risk posed by extreme events. In Proceedings of the Risk Management Strategies in an Uncertain World, New York, NY, USA, 12-13 April 2002.

48. Aven, T.; Renn, O. Risk management. In Risk Management and Governance; Springer: Berlin/Heidelberg, Germany, 2010; pp. 121-158.

49. Wachinger, G.; Renn, O.; Begg, C.; Kuhlicke, C. The Risk Perception Paradox-Implications for Governance and Communication of Natural Hazards. Risk Anal. 2013, 33, 1049-1065. [CrossRef]

50. Sandman, P.M. Risk Communication: Facing Public Outrage. Manag. Commun. Q. 1988, 2, $235-238$. [CrossRef]

(C) 2019 by the authors. Licensee MDPI, Basel, Switzerland. This article is an open access article distributed under the terms and conditions of the Creative Commons Attribution (CC BY) license (http://creativecommons.org/licenses/by/4.0/). 